Natalia Ganuza*, David Karlander and Linus Salö

\title{
A weave of symbolic violence: dominance and complicity in sociolinguistic research on multilingualism
}

https://doi.org/10.1515/multi-2019-0033

\begin{abstract}
This paper discusses symbolic violence in sociolinguistic research on multilingualism. It revisits an archived recording of a group discussion between four boys about their chances of having sex with a female researcher. The data is rife with symbolic violence. Most obviously, the conversation enacted a heterosexist form of symbolic violence. This was, however, not the only direction in which violence was exerted. As argued by (Bourdieu \& Wacquant. 1992. An invitation to reflexive sociology. Cambridge: Polity), symbolic violence involves two fundamental elements - domination and complicity. In the case at hand, the boys' sexist banter conformed to dominant expectations about their linguistic behavior, imbued in the research event. This is symbolic complicity of the kind that the Bourdieusian notion foresees. Yet another subordination to the dominant vision occurred when the researchers captured the conversation on tape, but decided to exempt it from publication. Here, we argue that giving deepened attention to sociolinguists' own run-ins with symbolic violence during research is valuable, because it provides an opportunity to reflexively consider the social conditions of the research practices, in relation to the data produced and analyzed. Ultimately, this reflexive exercise may help sociolinguists sharpen their tools for understanding the give and take of dominance and complicity unfolding in their data.
\end{abstract}

Keywords: multilingualism, sociolinguistic methods, symbolic violence, nonstandard Swedish

\footnotetext{
*Corresponding author: Natalia Ganuza, Department of Scandinavian Languages, Uppsala University, Box 527, Uppsala 751 20, Sweden, E-mail: natalia.ganuza@nordiska.uu.se https://orcid.org/0000-0002-0444-2207

David Karlander, Society of Fellows in the Humanities, School of English, University of Hong Kong, Hong Kong, E-mail: dakar@hku.hk

Linus Salö, Division of History of Science, Technology and Environment, KTH Royal Institute of Technology, Stockholm, Sweden, E-mail: ljsalo@kth.se
}

Ә Open Access. (C) 2020 Ganuza et al., published by De Gruyter. (cc) BY-NC-ND This work is licensed under the Creative Commons Attribution-NonCommercial-NoDerivatives 4.0 License. 


\section{Introduction}

In 2002, the first author of this article was a PhD candidate in the SUF project, a large research project interested in Swedish linguistic variation in multilingual neighborhoods. The SUF project (see detailed account below) intended to “describe, analyze and compare language and language use” (Boyd 2010: 4). Its design encompassed a range of methodological techniques to gather relevant data from the language practices of certain recruited participants: adolescents from ethnically and linguistically diverse areas in Sweden's three largest cities. A central concern was to "find out how people talk when they are not systematically observed” (Labov 1972: 209), with self-recordings and group-conversations being used to this end. During one of these sessions, which involved four 16 to 17 year-old male students at a Stockholm upper-secondary school, the following recording was made:

Excerpt $1 .^{1}$

\begin{tabular}{|l|l|l|}
\hline & ENGLISH TRANSLATION & ORIGINAL \\
\hline 1. & $\begin{array}{l}\text { Karwan: Hey if we baxar [steal] her } \\
\text { number \# and then we call her and } \\
\text { then maybe we can bazz [fuck] her. }\end{array}$ & $\begin{array}{l}\text { Karwan: Asså de om vi baxar hennes } \\
\text { nummer \# å sen vi ringer henne å sen vi } \\
\text { kanske kan bazz henne. }\end{array}$ \\
\hline 2. & Ekmel: Who? & Ekmel: Vem? \\
\hline 3. & Karwan: This Maria Andersson. & Karwan: Den hära Maria Andersson. \\
\hline 4. & $\begin{array}{l}\text { Ekmel: I don’t think she gives [\%gives } \\
\text { sex] len [dude]. }\end{array}$ & Ekmel: Jag tror inte hon ger len. \\
\hline 5. & $\begin{array}{l}\text { Mohammed: }<[>] \text { She gives she gives she } \\
\text { gives. }\end{array}$ & Mohammed: $<[>]$ Hon ger hon ger hon ger. \\
\hline 6. & Karwan: $<[>]$ Yes, believe me that she $+/$. & Karwan: $<[>]$ Jo tro mej att hon $+/$. \\
\hline 7. & Ekmel: She gives \# she gave to you huh? & Ekmel: Hon ger \# hon gav till dej hah? \\
\hline
\end{tabular}

As can be noted in this excerpt, contextualized in detail in Section 4, the four boys engaged in a discussion about their chances of having sex with "Maria Andersson." The name ${ }^{2}$ was printed on a label on the $\mathrm{mp} 3$ recorder placed on the table in front of the boys, and they accordingly assumed that "Maria

1 A key to the transcript is found at the end of the article.

2 "Maria Andersson" is a pseudonym, as are all other names of individuals used in the article. The actual name printed on the label of the mp3-recorder was a relatively common Swedish name, and the name of one of the SUF research assistants. 
Andersson" was one of the SUF researchers present at their school. This was a somewhat unexpected turn of events in the recording. Having gauged the sexist character of the transcript, the researchers decided to withhold it from publication. As the SUF project was concerned mainly with linguistic features, for example lexical register shibboleths (e. g. baxar, bazz; see Kotsinas 1994) or lack of subject-verb inversion (e.g. XSV-order; å sen.X vi.SUBJ ringer.VERB henne; see Ganuza 2008), less offensive examples were easy to find. This decision was also reflective of the SUF project's attempt to overcome the prevalence in earlier research (e. g. Kotsinas 1994) of stereotypical representations of the "speech of multilinguals" (see Boyd 2010: 3). These are understandable considerations that we do not seek to criticize. Yet, the unease that this transcription caused among the SUF researchers is nevertheless worthy of analytical attention. This is what we seek to provide in this article.

We maintain that Excerpt 1 points to a number of issues of general interest to sociolinguistics. In the following, we argue that giving deepened attention to research situations that cause unease in researchers is valuable for grasping some central epistemological and sociological issues in sociolinguistic research. When put to scrutiny, such situations, and the textual products they yield, may offer an understanding of the ways in which representation, domination, and subordination unfold in the relationship between researchers and the researched in sociolinguistic research (see also Briggs 2003; Cameron et al. 1993; Jaspers and Meeuwis 2013). We contend that through the practice of epistemic reflexivity (Bourdieu and Wacquant 1992, see also Salö 2018) the subtle modes of domination that are at play in the research design and practice can become more readily visible to the researcher. In this paper, we show how the data in Excerpt 1 can be viewed as a responsive product of symbolic violence in Pierre Bourdieu's sense that is, as an effect of the participants' compliance with and reaction to the order of dominance presupposed by the SUF research design (see Bourdieu 1991, Bourdieu 2007; Bourdieu and Passeron 1977; Bourdieu and Wacquant 1992).

\section{The SUF project revisited}

The project "Language and Language Use among Young People in Multilingual Urban Settings" (the SUF project for short, see Boyd 2010) ${ }^{3}$, was a research

3 The acronym SUF is based on the Swedish title of the project, "Språk och språbruk bland ungdomar i flerspråkiga storstadsmiljöer”. The project was funded by the Swedish Foundation for Humanities and Social Sciences 2001-2006 and led by Professor Inger Lindberg. 
initiative bringing together over a dozen Swedish researchers. It formed part of a large-scale attempt to get a firmer grasp on the "new" urban varieties of Swedish presumably spoken in socio-linguistically diverse, highly multilingual neighborhoods in Sweden's three largest cities: Stockholm, Gothenburg, and Malmö. In several regards, the SUF project aligned with a number of other, mainly European, sociolinguistic studies of urban multilingualism (for an overview, see, for example, Nortier and Svendsen 2015; Quist and Svendsen 2010). It examined late-modern urban vernaculars, the interrelatedness of multilingualism and linguistic variation, and the prevalence of such ways of speaking in the linguistic practices of adolescents. In Sweden at the time, Rinkebysvenska ("Rinkeby Swedish," henceforth RS) ${ }^{4}$ was a popular, but also increasingly contested, way of labeling a purported non-standard register held to be emblematic of youths from multilingual peripheral urban areas (e. g. Kotsinas 1988). In the media, RS was often depicted and discussed as something "bad," "deviant," and "un-Swedish," and over time it also came to be increasingly linked to transgression, criminal behavior, sexism, and the like (Bijvoet and Fraurud 2012; Jonsson 2007; Milani 2010; Milani and Jonsson 2011, Milani and Jonsson 2012; Stroud 2004).

The research interests of the SUF project were paired with a firm interest in empirical depth and detail. Seeking to create a comprehensive basis for primarily linguistic analyses, the researchers produced more than 400 hours of audio material. In total, 222 adolescents were recorded in a number of settings, such as classroom activities, interviews, peer group conversations, and self-recordings. Data also encompassed field notes, written assignments and various types of language tests. With that design followed a range of methodological considerations. For example, the reason why the participants in Excerpt 1 were left alone with the recorder had to do with the underlying aim of avoiding the "observer's paradox" (Labov 1972). If the presence of researchers was minimized, or so the reasoning went, the recorded material would come out as close as possible to "natural discourse." However, as argued in previous research (e. g. Jaspers and Meeuwis 2013) and as evidenced in Excerpt 1, the physical non-presence of the researchers did not always correlate with their discursive non-presence in the recorded conversations. As will be shown throughout this paper, the students relatively often reflected on the research situation and the researchers in ways that also revealed their sense of themselves as research participants. Aided by the recording equipment, which they fully controlled, they sometimes addressed researchers semi-directly in the microphone. In Excerpt 1, indicatively, the

4 Rinkeby is emblematically known as a densely populated "immigrant" urban area on the outskirts of Stockholm. 
students spoke on the assumption that "Maria Andersson" would listen to their conversation at a later stage. Furthermore, as will be illustrated below, such moments often encompassed sequences of verbal performance (cf. Bauman 2004; Rampton 2006; Jaspers and Meeuwis 2013). These instances of performance, we hold, are rife with what Pierre Bourdieu denotes symbolic violence, to which we now turn.

\section{Unpacking symbolic violence}

Sociolinguistic research, as Heller and McLaughlin (2017) note, has developed a thorough understanding of prevalent relations of power and domination in multilingual educational settings. In the current paper, we argue that the Bourdieusian notion of symbolic violence offers a particularly strong vantage point for developing a reflexive gaze on the workings of relations of power and domination at the level of practice. The core theme in Bourdieu's work on symbolic violence concerns the suffering of people who seemingly have come to terms with their position as symbolically or materially dispossessed and, in a sense, have accepted their fate as dominated (e.g. Bourdieu 2007). Acceptance is thus viewed as a fundamental component of violent relations. Violence, he reasoned, is not only exercised physically but also symbolically. According to Bourdieu, symbolic violence is "the violence which is exercised upon a social agent with his or her complicity" (Bourdieu and Wacquant 1992: 167, emphasis added). Complicity thus forms an essential element of the formula of symbolic violence. Present in virtually all social relations, though often veiled, symbolic violence relies on the tacit acceptance of inequity, which is perceived as natural and inescapable by both "the victims" and "the perpetrators."

Oftentimes, the exercise of symbolic violence is conceptualized in overtly unidirectional terms, as "a kind of violence being perpetuated on those not belonging to the dominant social groups" (Grenfell 2012: 267). While this general conception indeed holds true in some contexts, for example, in a large-scale overview of the educational system (e.g. Bourdieu and Passeron 1977), the patterns and directions of symbolic violence are less clear at the level of practice. This is so because a social agent can at once belong to both a dominant and a dominated group; for instance, a person may occupy a dominated position vis-à-vis one order (e. g. class or ethnicity) but a dominating position vis-à-vis another (e. g. gender). As Cameron et al. (1993: 88) argue, sociolinguistics have been prone to treat power as a reified object that can be possessed by individual 
agents. In relation to ethical and advocacy concerns, the researcher is typically seen as the one in power and the research participants as those without power. While this is often the case, it overlooks the fact that symbolic power is not allocated to a fixed set of social positions, and power is essentially relational. In a particular research situation, relations of domination may, thus, be continuously imposed, reworked and negotiated in interaction between researchers and the researched (Cameron et al. 1993: 87).

Accordingly, through the theoretical lens adopted in this article, symbolic violence is seen as working in multiple, yet ordered, ways. By speaking of "a weave" of symbolic violence we seek to draw attention to the back-and-forth pattern of such ordering. A given act of domination might constitute a first act of violence, but such an act might provoke retaliation, and be responded to by the dominated, not through resistance but through acts of counter-violence; that is, a new mode of domination can be triggered by the first one. The resulting weave of symbolic violence appears seamless, but in fact consists of a sequentially layered pattern of symbolically violent acts.

\section{Revisiting omitted data: Inroads toward grasping symbolic violence}

\subsection{Contextualizing the data}

Below, we analyze a 24-minute audio recording of a peer group conversation between four boys (Ekmel, Karwan, Metin and Mohammed, all pseudonyms). Parts of the recording center around a discussion of the short-story Elixir (Leiva Wenger 2001, see below), which the students had been assigned to read as homework for a Swedish class. At the time of the class, three members of the SUF research team were present in the school. The students discussed the text in groups and were presented with a set of questions about the story, which they were told could be used as a point of departure for their discussion. Hence, the short story and the questions act as some key features in the framing (Goffman 1974) of the overall conversation. The SUF researchers set up the recording equipment (mp3 players and microphones), but were not present during any of the discussions.

A brief introduction to the story Elixir is needed. It is eight pages long and was published in 2001 in an edition of Leiva Wenger's collected short stories. Upon publication, the short story collection was widely praised. Many literary 
critics lauded the author's innovative language use, which some early reviews described as a successful portrayal of "authentic suburban youth slang” (e. g. Källström 2005; Smalley 2012). In a lightly magical realist fashion, it comments on the marginalization of male immigrant youths. Its narrative centers on a group of Latino friends who one day mysteriously receive a package in the mail. The package contains a bottle of soda, an elixir, which supposedly turns anyone who tastes it into a "real Swede." Although the protagonists take pride in being - as they say - svartskallar ${ }^{5}$, they are unable to resist trying the contents of the bottle. After drinking it, they notice how they gradually morph into a stereotypical "Swedish" appearance - their hair getting blonder, and their eyes bluer. Their behavior also changes - they start acting like "typical Swedes." Suddenly, they are able to concentrate in school, barely remember any Spanish, and even find themselves unable to jump the turnstiles at the metro station. In the text, Leiva Wenger thus plays with two widely circulated stereotypes: the badly behaved boy with a dark complexion and immigrant background who underperforms at school, and the Nordic-looking, standard Swedish-speaking model student.

The hyper-reflexive language of the story reinforces this dynamic. As described elsewhere (e.g. Källström 2005), the story is replete with stylized colloquial language, scarce punctuation, a mix of upper- and lower-case letters, idiosyncratic spelling, and non-conventional loan words, as well as expressions and constructions associated with urban vernacular Swedish and multilingual speakers. The SUF research team was responsible for choosing the Elixir story and presenting it to the teachers in the schools. The story was chosen as it was deemed beneficial to the purpose of eliciting interesting discussions about youth language. However, in retrospect, little thought was put into how this choice of text might affect the participants' perception and understanding of the research objectives. While the intent of the research design was to create minimal interference, the choice of text seems to have revealed and accentuated the researchers' interest in non-standard urban Swedish.

\subsection{Complying with dominant representations of "Rinkeby Swedish"}

The participants' heightened awareness of the research objective is evident throughout the recording. Already prior to the part of the recording presented

5 Svartskalle (svartskallar in plural) is a racist term in Swedish pointing to non-Nordic bodily features, literally referring to a "black head" or a "black head of hair". 
in Excerpt 2, it was apparent that Ekmel suspected that he and his friends had been typecast as a group able to perform being "speakers of RS." While the other boys tried to recapitulate the gist of the short story, Ekmel continuously interjected a variety of expletives and slang words into their ongoing account, such as "horunge” (son of a whore), “abou” (hey, wow), "bögjävel” (faggot, fag), "gitta” (get out of here), "len" (dude, mate), "amcık" (little cunt; not included in the excerpt). At one point, he exclaimed "I know cool language man, backward, forward, consonants and vowels.” Through these interventions, Ekmel seemed to perform compliance with the presumed expectation that he can produce nonstandard RS linguistic forms, and shared with the researchers a glimpse of a social reality that agreed with this expectation (cf. Slembrouck 2004). This performative meta-commentary continued throughout the recording.

A short while after his initial outbursts, Ekmel read the fifth question presented to them on the question sheet, which asked: "Why do you think the author has chosen to write the way he does?” (Excerpt 2, line 1).

Excerpt 2.

\begin{tabular}{|l|l|l|}
\hline & ENGLISH TRANSLATION & ORIGINAL \\
\hline 1. & $\begin{array}{l}\text { Ekmel: Why do you think the author has } \\
\text { chosen to write the way he does? He } \\
\text { wants to be a wannabe svartskalle that's } \\
\text { why, or? }\end{array}$ & $\begin{array}{l}\text { Ekmel: Varför tror ni att författaren har } \\
\text { valt att skriva som han gör? Han vill bli } \\
\text { wannabe svartskalle därför, eller? }\end{array}$ \\
\hline 2. & Metin: I don't know. & Metin: Jag vet inte. \\
\hline 3. & Karwan: Yeah. & Karwan: Ah. \\
\hline 4. & $\begin{array}{l}\text { Ekmel: He can't even spell bre [man]. } \\
\text { Can't you see how he has spelled guz } \\
\text { [girl]? Guz with one Z. That doesn't work. } \\
\text { It's with two Z's. Göt [ass] that's not with } \\
\text { one T it's with two T's. }\end{array}$ & $\begin{array}{l}\text { Ekmel: Han kan inte ens stava bre. Ser du } \\
\text { zöte hur han har stavat guz? Guz med ett } \\
\text { Göt det inte med ett t de e med två t. }\end{array}$ \\
\hline
\end{tabular}

Having read the question aloud, Ekmel immediately claimed that the author wrote the way he did to give the (false) impression of being an authentic svartskalle. Ekmel motivated his claim by pointing out some misspelled slang words used in the story (see line 4). Implicit in his account is that if the author had been a real svartskalle, like them, he would have known how to spell these words correctly. Hence, the author's misspellings were taken as signs of his inauthenticity. Notably, Ekmel motivated this by using a normative language ideology argument.

At this point in the recording, the boys started to discuss the actual meaning of the word "elixir," initiating a long sequence where Ekmel improvised an 
elaborate account of the origins of the word (not reproduced in the excerpt). Speaking in what he labeled "philosophical terms," he jokingly invoked the image of an "Iranian installing an electrical appliance." He repeatedly pronounced the Swedish word for the electricity ("elen," ['e:len]) in a supposedly Farsi fashion, producing a drawn-out final syllable with a raised, elongated and nasalized vowel (i.e. [e:'lĩ:]). As the joke proceeded, the Iranian electrician increasingly distorted the original word, lacing it with various other lexical elements and flawed pronunciations, eventually morphing it into elixir (see also Werndin 2010). The other boys were not amused by Ekmel's long excursus, after which Karwan volunteered an alternative explanation, with direct reference to the content of the short story (reproduced in Excerpt 3, lines 1 and 3). Nevertheless, Ekmel dismissed this explanation and concluded that he had never heard the word "elixir" before, since "it doesn't exist in Rinkeby Swedish" (see line 8).

Excerpt 3.

\begin{tabular}{|l|l|l|}
\hline & ENGLISH TRANSLATION & ORIGINAL \\
\hline 1. & $\begin{array}{l}\text { Karwan: [\%laughs] But \# but honestly } \\
\text { wait, do you know where elixir comes } \\
\text { from? }\end{array}$ & $\begin{array}{l}\text { Karwan: [\%laughs] Men \# men ärligt } \\
\text { vänta, vet du var elixir kommer ifrån? }\end{array}$ \\
\hline 2. & Ekmel: No. & Ekmel: Näe. \\
\hline 3. & $\begin{array}{l}\text { Karwan: It's that bottle that he got that } \\
\text { he drank \# surely it's that. }\end{array}$ & $\begin{array}{l}\text { Karwan: Det e den där flaskan som han } \\
\text { fick som han drack \# säkert det där. }\end{array}$ \\
\hline 4. & Ekmel: That they drank? & Ekmel: Som dom drack? \\
\hline 5. & Karwan: That he, yeah. & Karwan: Som han, ah \\
\hline 6. & Ekmel: Ah but it said nothing about that. & Ekmel: Ah men det stod ingenting om det. \\
\hline 7. & $\begin{array}{l}\text { Karwan: Well I don't know, but let’s } \\
\text { make a guess. }\end{array}$ & Karwan: Men jag vet inte, men vi chansar \\
\hline 8. & $\begin{array}{l}\text { Ekmel: What does the word mean and } \\
\text { what is it? I have never heard about elixir. } \\
\text { It doesn't exist in Rinkeby Swedish elixir. } \\
\text { Have you heard about elixir? }\end{array}$ & $\begin{array}{l}\text { Ekmel: Va betyder ordet och vad är det? } \\
\text { finns inte med i rinkebysvenska elixir. } \\
\text { Har du hört talas om elixir? }\end{array}$ \\
\hline 9. & Mohammed: No. & Mohammed: Nej. \\
\hline
\end{tabular}

Both Excerpts 2 and 3 illustrate how the participants' representation of the research objective clearly included an explicit focus on RS, despite this not being mentioned by the SUF researchers, and how they anticipated a focus on their ability to discuss, perform and identify with the non-standard form of 
Swedish. In effect, they also complied with these expectations through their interactions. Furthermore, as exemplified in the next Excerpt (4), the boys anticipated an evaluation of their language use in relation to standard Swedish. In response to the question "What do you think about the story?" all four participants agreed that it was "not good." They agreed it should be awarded a failing grade. However, when Metin suggested that the reason was that the language was not good (see Excerpt 4, line 7), he was immediately heckled by the other participants. They contested the legitimacy of Metin's attempt to criticize the quality of the language, on the grounds of where he comes from. When Metin insisted that the author did not use "real Swedish" (line 12), Ekmel countered that Metin was trying to act smart, or, in Karwan's words, that he was trying to pass as a "pure-speaking Swede" (line 14), despite merely being a "chat Turk" (a derogatory label for immigrants quite commonly used at the time, see line 15).

Excerpt 4.

\begin{tabular}{|c|c|c|}
\hline & ENGLISH TRANSLATION & ORIGINAL \\
\hline 1. & Ekmel: What do you think of the story? & Ekmel: Vad tycker du om berättelsen? \\
\hline 2. & $\begin{array}{l}\text { Karwan: Okey it wa:s it was keff [bad] it } \\
\text { was bad. }\end{array}$ & $\begin{array}{l}\text { Karwan: Okej den va: den va keff den va } \\
\text { dålig. }\end{array}$ \\
\hline 3. & Metin: It gets $I G$ [\%failing grade] honestly. & Metin: Den får IG ärligt talat \\
\hline 4. & Ekmel: $<[>] I G$ right? Nailed, totally. & Ekmel: $<[>]$ IG va? Spikat, galet. \\
\hline 5. & Mohammed: $<[>]$ Yeah $I G$. & Mohammed: $<[>]$ Yeah IG. \\
\hline 6. & Ekmel: $I G$ yeah. & Ekmel: IG a:h. \\
\hline 7. & Metin: It's not good language. & Metin: De e inge bra språk. \\
\hline 8. & $\begin{array}{l}\text { Ekmel: }<[>] \text { Yeah but what do you sa+ where } \\
\text { do you come from len [dude] [\%laughs] }\end{array}$ & $\begin{array}{l}\text { Ekmel: }<[>] \text { Ah men va sna+ var kommer } \\
\text { ru ifrån len [\%skrattar] }\end{array}$ \\
\hline 9. & Metin: $<[>]$ [\%laughs] & Metin: $<[>]$ [\%skrattar] \\
\hline 10. & $\begin{array}{l}\text { Ekmel: }\langle[>] \text { Where do you come from? Do } \\
\text { you live in Bla+ Bla+ what it's called eh } \\
\text { Blackeberg [\% [\%ame of neighborhood in } \\
\text { Stockholm]. }\end{array}$ & $\begin{array}{l}\text { Ekmel: }<[>] \text { Var kommer ru ifrån? Bor ru } \\
\text { i Bla+ Bla+ va heter re öh Blackeberg [\% } \\
\text { namn på område i Stockholm]. }\end{array}$ \\
\hline 11. & $\begin{array}{l}\text { Karwan: }<[>] \text { But it's not good language } \\
\text { [\%laughs and ironically imitates Metin's } \\
\text { previous comment]. }\end{array}$ & $\begin{array}{l}\text { Karwan: }<[>] \text { Men de e inge bra språk }[\% \\
\text { skrattar och upprepar ironiskt Metins } \\
\text { tidigare kommentar]. }\end{array}$ \\
\hline 12 & $\begin{array}{l}\text { Metin: }<[>] \text { He doesn’t use Swedish a real } \\
\text { Swedish. }\end{array}$ & $\begin{array}{l}\text { Metin: }\langle[>] \text { Han använder inte svenska } \\
\text { en riktig svenska. }\end{array}$ \\
\hline
\end{tabular}




\begin{tabular}{|c|l|l|}
\hline 13. & $\begin{array}{l}\text { Ekmel: Yeah but the bloke is acting chok } \\
\text { [really] smart, right? }\end{array}$ & $\begin{array}{l}\text { Ekmel: Ah men snubben han leker chok } \\
\text { smart asså. }\end{array}$ \\
\hline 14. & Karwan: He is a pure-speaking Swede. & Karwan: Han e rentalande svensk. \\
\hline 15. & $\begin{array}{l}\text { Ekmel: He is a pure-speaking Swede \# } \\
\text { he's a chat Turk. }\end{array}$ & $\begin{array}{l}\text { Ekmel: Han e rentalande svensk \# han e } \\
\text { en chatturk. }\end{array}$ \\
\hline
\end{tabular}

It is not too far-fetched to interpret Metin's comment about the language not being correct or real Swedish as a demonstration to the researchers of his mastery of acknowledged standard registers of Swedish, in opposition to the presumed expectation of their being able to perform as speakers of RS. Hence, all of the participants, albeit in different manners, responded to what they perceived to be an implicit evaluation of their linguistic competence imbued in the research event. At this stage in the conversation, however, Metin was the only one who did not comply with the assumption that they would be able to align and identify with the language used in the short story. Nevertheless, as Excerpt 4 has illustrated, he was an accomplice in reproducing the common idea that non-standard Swedish is neither "good" nor "real" Swedish.

\subsection{Dominating the researcher, dominating the researched}

As soon as the boys had finished discussing the questions about the short story, Metin asked if he should turn off the recording device (see Excerpt 5, line 1). This comment clearly marked the end of the previous activity. With a sigh, Ekmel objected, suggesting that they should let the recording continue instead (line 2). As evidence of the transition from a more to a less monitored activity, Karwan suggested they could now sing (line 4), but then also daringly asked the others if they should steal the recording equipment (see line 7), to which he added "she's recording it," with a thrill in his voice. This comment shows how the recording device, through the pronoun "she," was conceived of as a mechanical incarnation of a female individual, presumably one of the female researchers (and future listeners, cf. Heller 2011). There are various instances in the SUF database where participants talked about stealing the recording device (see also Madsen 2015, in Denmark). It thus appears to be a relatively common reaction to the fact that the recorder physically represents the on-going surveillance of their interactions.

At the end of Excerpt 5, in response to Mohammed's suggestion to erase the comments about stealing the recorder (line 13), Ekmel once again insisted that they should just leave it on. This comment can be seen as an overt manifestation 
of the boys' performance for the overhearing audience. Overall, Excerpt 5 exemplifies how the physical non-presence of the researchers during the recording did not hinder their discursive presence, as materialized through the recording device.

Excerpt 5.

\begin{tabular}{|c|c|c|}
\hline & ENGLISH TRANSLATION & ORIGINAL \\
\hline 1. & Metin: Well, ok, should we stop? & Metin: Men ah okej ska vi stoppa? \\
\hline 2. & Ekmel: No, leave it on [\%sighs]. & Ekmel: Nej, låt den va på [\%gäspar]. \\
\hline 3. & Metin: Okay. & Metin: Okej. \\
\hline 4. & Karwan: Okay, now we can sing. & Karwan: Okej, nu vi kan sjunga. \\
\hline 5. & Ekmel: Yeah [\%sighs loudly]. & Ekmel: Ah [\%gäspar högt]. \\
\hline 6. & $\begin{array}{l}\% \text { com: someone starts drumming loudly } \\
\text { on the table. }\end{array}$ & $\begin{array}{l}\text { \%com: någon börjar trumma hårt på } \\
\text { bordet. }\end{array}$ \\
\hline 7. & $\begin{array}{l}\text { Karwan: Should we bax [steal] this. } \\
\text { She's recording it [\%laughs]. }\end{array}$ & $\begin{array}{l}\text { Karwan: Ska vi bax den här. Hon spelar } \\
\text { in det [\%skrattar]. }\end{array}$ \\
\hline 8. & $\begin{array}{l}\text { Ekmel: }<[>] \text { Son of a whore we bax [steal] } \\
\text { it and then we sell it [\%laughs at loud] } \\
\text { they hear us, you know that, right? }\end{array}$ & $\begin{array}{l}\text { Ekmel: Horunge vi bax den å sen vi säljer } \\
\text { ren [\%skrattar högt] dom hör oss du vet } \\
\text { de va? }\end{array}$ \\
\hline 9. & Metin: $<[>]$ [\%laughs] & Metin: $<[>][\%$ skrattar $]$ \\
\hline 10. & Karwan: No, really? [\%ironically] & Karwan: Nej, ä re sant? [\%ironiskt] \\
\hline 11. & $\begin{array}{l}\text { Mohammed: }\langle[>] \text { What do they hear us } \\
\text { now right away? }\end{array}$ & $\begin{array}{l}\text { Mohammed: }<[>] \text { Va hör dom oss direkt } \\
\text { nu på en gång? }\end{array}$ \\
\hline 12. & $\begin{array}{l}\text { Ekmel: }<[>] \text { Son of a whore yeah they }+/ \text {. } \\
<\text { arre }>\text { [?] what, do you think they hear us } \\
\text { now right away? Do you think it's a wire- } \\
\text { less thing? They will listen len [dude]. } \\
\text { But then when they listen and then they } \\
\text { will spräcklish [destroy] us. }\end{array}$ & $\begin{array}{l}\text { Ekmel: }<[>] \text { Horunge ah dom }+/ .<\text { arre }>[?] \\
\text { tror ru dom hör oss nu direkt på en gång? } \\
\text { Tror ru det e en trådlös grej? Dom ska } \\
\text { lyssna len. Men sen när rom lyssnar å } \\
\text { sen dom ska spräcklish oss. }\end{array}$ \\
\hline 13. & Mohammed: But we erase. & Mohammed: Men vi tar bort. \\
\hline 14 & $\begin{array}{l}\text { Ekmel: What should we erase len [dude]. } \\
\text { Leave it alone. Let them hear bre [man]. }\end{array}$ & $\begin{array}{l}\text { Ekmel: Vad ska vi ta bort len. Låt den va. } \\
\text { Låt dom höra bre. }\end{array}$ \\
\hline
\end{tabular}

Following this exchange, Karwan acknowledged the sticker attached to the mp3 player, which had the name "Maria Andersson" written on it (see Introduction). The sticker also gave her mobile phone number and her current workplace: the Rinkeby Language Research Institute. After Karwan matter-of-factly noted that the recorder belonged to "Maria Andersson," Ekmel commented on the researcher's appearance (see Excerpt 6, line 2), after which Karwan simply asked him "Is she a 
cat?” (line 3). Here, and in Swedish non-standard registers more generally, "cat” is used adjectively to denote (female) attractiveness. At this stage, however, Ekmel evaded the concealed sexual remark by answering "No, she is human" (line 6).

The exchange in Excerpt 6 can be interpreted as the boys' first attempt to shift the observing gaze away from themselves and onto the researcher (cf. Jaspers and Meeuwis 2013: 736). It also marked the beginning of a reversal in the direction of symbolic violence, where the female researcher, rather than the boys and their language use, slowly became the discursively dominated object.

Excerpt 6.

\begin{tabular}{|l|l|l|}
\hline & ENGLISH TRANSLATION & ORIGINAL \\
\hline 1. & Karwan: It’s Maria Andersson's. & Karwan: Det e Maria Anderssons. \\
\hline 2. & $\begin{array}{l}\text { Ekmel: A:h \# ah Maria that's her, you } \\
\text { know, with brown brown hair len [dude]. }\end{array}$ & $\begin{array}{l}\text { Ekmel: Åh \# ah Maria det e hon den } \\
\text { dära du vet med bruna brunt hår len. }\end{array}$ \\
\hline 3. & Karwan: Is she a cat? & Karwan: E hon katt? \\
\hline 4. & Ekmel: \# U:h what did you say [\%laughs]. & Ekmel: \# Ö:h vad sa ru [\%skratt]. \\
\hline 5. & Karwan: Is she a cat? & Karwan: Är hon katt? \\
\hline 6. & Ekmel: Uhm no, she is human [\%laughs]. & $\begin{array}{l}\text { Ekmel: Öh nä, hon e människa [\% } \\
\text { skrattar]. }\end{array}$ \\
\hline 7. & Karwan: Really, so boring. & Karwan: Asså vad tråkigt. \\
\hline
\end{tabular}

When Karwan observed that the female researcher's mobile phone number was written on the mp3-player (see Excerpt 7, line 1), Mohammed suggested they should use it to make a prank call, which then led Ekmel to start formulating a fake personal ad for the female researcher (line 6). This was the first time in the recording that an explicitly sexual remark was made about the researcher; which was further expanded when Mohammed added that "she is a schlajn [slut]" (line 9). After making sure that Mohammed was aware of whom they were making fun (line 11), Ekmel stated that "Maria Andersson" would get really angry when she listened to the recording later (line 14). Subsequently, both Mohammed and Ekmel addressed "Maria" directly in the microphone, attempting to exempt themselves from responsibility for the earlier comments (see lines 15-16).

The last section of Excerpt 7 illustrates how Ekmel and Karwan could not understand why the researcher would write her name and phone number on a new mp3-player, since nobody would return it to her if it was lost (Excerpt 7, lines 17-22). This was expressed in a tone that insinuated how absurd the idea was - maybe even to the point of justifying their ridicule of her. However, alluding to the content of the short story, the boys suggested that they would 
have returned the recorder if they were Swedes (line 21), if they had drunk the elixir that turned one into a Swede (line 22). These statements show how the short story continued to exert influence on the conversation even when it was no longer in focus, and how the participants used it to position themselves and the researcher in relation to an imagined "real Swede." While they positioned themselves as not belonging to the category of "svenne" [Swede], they clearly assigned this position to "Maria Andersson." The examples also illustrate how the boys, with the help of the story, created indexical links between stereotypical Swedishness and behavior that is good and honest, but also naïve, vs. stereotypical non-Swedishness and behavior that is disruptive and dishonest (see similar examples in Jonsson and Milani 2012; Milani and Jonsson 2011, Milani and Jonsson 2012).

Excerpt 7.

\begin{tabular}{|c|c|c|}
\hline & ENGLISH TRANSLATION & ORIGINAL \\
\hline 1. & $\begin{array}{l}\text { Karwan: Hey, her mobile phone number } \\
\text { is on here and stuff. }\end{array}$ & $\begin{array}{l}\text { Karwan: Hörru hennes mobilnummer } \\
\text { står här å grejer. }\end{array}$ \\
\hline 2. & Ekmel: I swear. & Ekmel: Jag svär. \\
\hline 3. & Mohammed: Yeah we we write it in. & Mohammed: Ja vi vi skriver in den. \\
\hline 4. & Ekmel: Alright. & Ekmel: Alright. \\
\hline 5. & $\begin{array}{l}\text { Mohammed: Should we make a prank } \\
\text { call should we make a prank call? }\end{array}$ & $\begin{array}{l}\text { Mohammed: Ska vi tjuvringa ska vi } \\
\text { tjuvringa? }\end{array}$ \\
\hline 6. & $\begin{array}{l}\text { Ekmel: Ye:ah \# then we will eh take ad. } \\
\text { Personal ad for Maria Andersson. Her } \\
\text { mobile number is 0736-XXX. }\end{array}$ & $\begin{array}{l}\text { Ekmel: A:h \# då ska vi eh ta annons. } \\
\text { Kontaktannons för Maria Andersson. } \\
\text { Hennes mobilnummer är 0736-XXX. }\end{array}$ \\
\hline 7. & Karwan: Repeat. & Karwan: Repetera. \\
\hline 8. & Ekmel: I repeat 0736-XXX. & Ekmel: Jag repeterar 0736-XXX . \\
\hline 9. & Mohammed: And she is a schlajn [slut]. & Mohammed: Å hon e ett schlajn. \\
\hline 10. & Karwan: Sch+. & Karwan: Sch+. \\
\hline 11. & $\begin{array}{l}\text { Ekmel: [\%laughs] Schlajn [slut] eh hey } \\
\text { it's she who's here, you know [\%laughs]. }\end{array}$ & $\begin{array}{l}\text { Ekmel: [\%skrattar] Schlajn öh hörru de e } \\
\text { hon som e här du vet [\%skrattar]. }\end{array}$ \\
\hline 12. & Mohammed: Is it hers? & Mohammed: Ä re hennes? \\
\hline 13 & $\begin{array}{l}\text { Karwan: }<[>] \text { Yeah yeah yeah one of } \\
\text { those [\%laughs] xxx. }\end{array}$ & $\begin{array}{l}\text { Karwan: }<[>] \text { Ah ah ah en av dom där }[\% \\
\text { skrattar] xxx. }\end{array}$ \\
\hline 14. & $\begin{array}{l}\text { Ekmel: }\langle[>] \text { Yes [\%laughs] when she lis- } \\
\text { tens to this she will get chok lack [really } \\
\text { pissed off] guys [\%laughs]. }\end{array}$ & $\begin{array}{l}\text { Ekmel: }<[>] \text { Ja [\%skrattar] \# när hon lyss- } \\
\text { nar på re här hon kommer bli chok lack } \\
\text { asså grabbar [\%skrattar]. }\end{array}$ \\
\hline
\end{tabular}




\begin{tabular}{|c|c|c|}
\hline 15. & $\begin{array}{l}\text { Mohammed: }<[>]<\text { Maria it }>\text { [?] wasn't } \\
\text { me. }\end{array}$ & $\begin{array}{l}\text { Mohammed: }<[>]<\text { Maria det }>\text { [?] var inte } \\
\text { jag. }\end{array}$ \\
\hline 16. & $\begin{array}{l}\text { Ekmel: }<[>] \text { It wasn't me len [dude] [\% } \\
\text { laughs]. }\end{array}$ & $\begin{array}{l}\text { Ekmel: }\langle[>] \text { Det var inte jag len }[\% \\
\text { skrattar]. }\end{array}$ \\
\hline & [...] $13 \mathrm{~s}$. & [...] $13 \mathrm{~s}$. \\
\hline 17. & $\begin{array}{l}\text { Ekmel: Hey, why would you write your } \\
\text { mobile [\%tutting]. Hey, if she'd lost that } \\
\text { one \# would you go and return it? }\end{array}$ & $\begin{array}{l}\text { Ekmel: Asså varför ska man skriva mobil } \\
\text { [\%smackljud]. Asså, om hon skulle tap- } \\
\text { pat den dära \# skulle ru gå å lämna ren? }\end{array}$ \\
\hline 18. & Karwan: No. & Karwan: Näe. \\
\hline 19. & Ekmel: $<[>]$ [\%laughs]. & Ekmel: $<[>]$ [\%skrattar]. \\
\hline 20. & $\begin{array}{l}\text { Karwan: }<[>] \text { Never }[\% \text { laughs]. Hell, } \\
\text { totally new, why should I return it? }\end{array}$ & $\begin{array}{l}\text { Karwan: }<[>] \text { Aldrig [\%skrattar]. Helt ny } \\
\text { va fan, vad ska jag lämna den? }\end{array}$ \\
\hline 21. & $\begin{array}{l}\text { Ekmel: If you were a svenne [Swede] you } \\
\text { would have done it. }\end{array}$ & $\begin{array}{l}\text { Ekmel: Om du va svenne då du skulle ha } \\
\text { gjort det. }\end{array}$ \\
\hline 22. & $\begin{array}{l}\text { Karwan: If I would've dru+ drunk that } \\
\text { thing. }\end{array}$ & $\begin{array}{l}\text { Karwan: Om jag dru+ hade druckit den } \\
\text { där grejen. }\end{array}$ \\
\hline
\end{tabular}

Following the exchange reproduced in Excerpt 7, the conversation drifted to other topics. Then, suddenly, the sticker on the recorder again caught the boys' attention, reigniting their interest in "Maria Andersson." As can be seen at the beginning of Excerpt 8, Karwan suggested "if we bax [steal] her number, and then we call her, and then maybe we can bazz [fuck] her" (line 1). Before this exclamation, Mohammed had asked Karwan about his ethnic background, Mohammed's curiosity having been sparked by an image of a flag on one of Karwan's books. In the recording, Karwan answered Mohammed's questions rather hesitantly. Hence, it is possible that his explicit suggestion to bazz Maria was an attempt to divert attention away from himself. Ekmel gradually began to engage in the sexualizing banter about the young female researcher, which escalated once Mohammed insisted that the name "Maria" sounded like a "schlajn [slut]" (line 12, see also Excerpt 7, line 9), or even "pornographic" (line 16), like someone who " 'gives' to everyone, all at once" (line 12). Ekmel agreed that her name sounded "kind of slutty" (line 15), which once again made him associate the name with a personal ad advertising sex (line 17, as he also did in Excerpt 7). These accounts thus illustrate how the common female name "Maria" sparked a series of sexual associations. However, the most imaginative remark was made by Mohammed when he asserted that the researcher "likes Rinkeby Swedish while you fuck her" (line 20), to which Karwan added "so you should call her whore while you bazz [fuck] her" (line 22). 
Excerpt 8.

\begin{tabular}{|c|c|c|}
\hline & ENGLISH TRANSLATION & ORIGINAL \\
\hline 1. & $\begin{array}{l}\text { Karwan: Hey if we baxar [steal] her num- } \\
\text { ber \# and then we call her and then } \\
\text { maybe we g+ can bazz [fuck] her. }\end{array}$ & $\begin{array}{l}\text { Karwan: Asså de om vi baxar hennes } \\
\text { nummer \# å sen vi ringer henne å sen } \\
\text { vi kanske g+ kan bazz henne. }\end{array}$ \\
\hline 2. & Ekmel: Who? & Ekmel: Vem? \\
\hline 3. & Karwan: This Maria Andersson. & Karwan: Den hära Maria Andersson. \\
\hline 4. & Ekmel: I don't think she gives len [dude]. & Ekmel: Jag tror inte hon ger len. \\
\hline 5. & $\begin{array}{l}\text { Mohammed: }<[>] \text { She gives she gives she } \\
\text { gives. }\end{array}$ & $\begin{array}{l}\text { Mohammed: }<[>] \text { Hon ger hon ger hon } \\
\text { ger. }\end{array}$ \\
\hline 6. & $\begin{array}{l}\text { Karwan: }<[>] \text { Yes, believe me that she } \\
+/ \text {. }\end{array}$ & Karwan: $<[>]$ Jo tro mej att hon $+/$. \\
\hline 7. & Ekmel: She gives \# she gave to you hah? & Ekmel: Hon ger \# hon gav ti(ll) dej hah? \\
\hline 8. & Mohammed: No no, she gave to a friend. & Mohammed: Nä nä, hon gav till en kompis. \\
\hline 9. & Ekmel: She gave to \# your friend? & Ekmel: Hon gav till \# din kompis? \\
\hline 10. & $\begin{array}{l}\text { Karwan: Well, that's what it is. She hasn't } \\
\text { gotten any for a long time uh now also. }\end{array}$ & $\begin{array}{l}\text { Karwan: Asså det e det. Hon har inte fått } \\
\text { på länge eh nu också. }\end{array}$ \\
\hline 11. & $\begin{array}{l}\text { Ekmel: [\%laughs] Seriously, she gave to } \\
\text { your friend? [\%com: accompanied by a } \\
\text { drum roll on the table] }\end{array}$ & $\begin{array}{l}\text { Ekmel: [=! skrattar] Allvar hon gav till } \\
\text { din kompis? [\%com: ackompanjerat av } \\
\text { en trumvirvel på bordet] }\end{array}$ \\
\hline 12. & $\begin{array}{l}\text { Mohammed: Maria that sounds like a } \\
\text { schlajn [slut] }<[>] \text { I think she gives to } \\
\text { everyone \# all at once. }\end{array}$ & $\begin{array}{l}\text { Mohammed: Maria de låter som ett } \\
\text { schlajn }<[>] \text { jag tror hon ger alla \# på en } \\
\text { gång. }\end{array}$ \\
\hline 13 & Ekmel: $<[>]$ [\% laughs loudly]. & Ekmel: $<[>]$ [\%skrattar högt]. \\
\hline 14. & Karwan: $<[>](\mathrm{xxx})$ & Karwan: $<[>]$ (xxx). \\
\hline 15. & $\begin{array}{l}\text { Ekmel: }\langle[>] \text { Yeah you're right it sounds } \\
\text { kind of schlajny [slutty] \# Maria it sounds } \\
\text { like a personal } \mathrm{a}+/ .\end{array}$ & $\begin{array}{l}\text { Ekmel: }<[>] \text { Ja eller hur det låter sådär } \\
\text { lite schlajnigt \# Maria, det } \mathrm{s}+\text { det låter } \\
\text { såhär kontakta }+/ \text {. }\end{array}$ \\
\hline 16. & Mohammed: Pornographic. & Mohammed: Pornografiskt. \\
\hline 17. & $\begin{array}{l}\text { Ekmel: Yeah right, personal ads they } \\
\text { have like Maria call horny Maria like } \\
\text { that, am I right? }\end{array}$ & $\begin{array}{l}\text { Ekmel: Ah eller hur kontaktsidorna dom } \\
\text { har såhär Maria ring kåta Maria typ } \\
\text { sådära, eller hur? }\end{array}$ \\
\hline 18. & Mohammed: Yeah. & Mohammed: Ah. \\
\hline 19. & Ekmel: Ok, so she gave $+/$. & Ekmel: Ah \# så hon gav +/. \\
\hline 20. & $\begin{array}{l}\text { Mohammed: She likes Rinkeby Swedish } \\
\text { while you fuck her \# you should speak } \\
\text { Rinkeby Swedish to her. }\end{array}$ & $\begin{array}{l}\text { Mohammed: Hon gillar rinkebysvenska } \\
\text { när du knullar henne \# du ska prata } \\
\text { rinkebysvenska med henne. }\end{array}$ \\
\hline
\end{tabular}




\begin{tabular}{|l|l|l|}
\hline 21. & Ekmel: She likes that yeah. & Ekmel: Hon gillar sånt äh. \\
\hline 22. & $\begin{array}{l}\text { Karwan: So you should call her whore } \\
\text { while \# you bazz [fuck] her. }\end{array}$ & $\begin{array}{l}\text { Karwan: Så du ska kalla henne för hora } \\
\text { medans \# du bazz henne. }\end{array}$ \\
\hline
\end{tabular}

The verbal sexual banter continued for another couple of minutes. Then, as some of their classmates entered the room, Ekmel tried to stage a short performance where he asked one of them to act as if he was the one who had had sex with "Maria Andersson." Ekmel even presented him with a short improvised dialogue, which he suggested should be enacted "with some accent, amclk [you little cunt]." When the classmate refused to play along, Ekmel once again asserted that "when she hears this she will spräckish [destroy] us, she's gonna töjish [stretch] us, you know." Hence, once more he explicitly directed attention to the transgressive nature of their articulated provocations and to the fact that the researcher would listen to them later. Remarkably, all of these interactions are loaded with linguistic features emblematic of RS (e. g. typical slang, the use of the verbal suffix -ish, and lack of subject-verb inversion, see Kotsinas 1988, Kotsinas 1994). Throughout their interactions, the boys thus continued their compliance with the presumed expectation that they were able to perform being speakers of RS.

Many possible layers of meaning are embedded in the accounts reproduced in excerpts 7 and 8. The element of risk-taking in explicitly talking about the desirability of the female researcher and about engaging in sexual activities with her can be interpreted as a peer-group performance of masculinity and heterosexuality (Cameron and Kulick 2003: 115; Kiesling 2005: 696; see also Milani and Jonsson 2011). Their recurring laughter, and the incrementally escalating nature of their provocations point in this direction. Mohammed's explicit comment (Excerpt 8, line 20) can be read as both an acknowledgment and mockery of the researcher's apparent infatuation with RS - an image of her being so interested in the research objective that she even enjoys hearing it during sex. In addition, Karwan's comment (line 22) indexically links RS to sexist language, which as mentioned earlier was a common stereotype about "immigrant youngsters," and later also of male indexically non-Swedish, non-standard speakers, depicted in the media at the time (see Milani 2010; Milani and Jonsson 2011, Milani and Jonsson 2012). However, we also interpret the interactions reproduced here as instances where the participants reacted to the first-order act of violence imbued in the research process by retaliating with counter-violence. Through their counter-reactions, they assumed a dominating male position over the female researcher (Bourdieu 2001). In this way, we contend, the examples illustrate the symbolic struggle over who has the power and legitimacy to objectify whom during the research process: 
Given that the fieldworker, through the recording device, suddenly obtains immediate and unmediated access to their "territories of the self" (Goffman 1974: $38 \mathrm{ff}$ ), it may not be unreasonable to suggest that the fieldworker's representation, among other things, as a sexual object can be read as a symbolic compensation, indeed as a re-penetration and degradation for being put in a vulnerable position. (Jaspers and Meeuwis 2013: 742)

At the very end of the recording, it became clear that Karwan had not even known who they were making fun of, as he asked Ekmel to point out "Maria Andersson" to him in the classroom. Ekmel's answer showed that he did not know who she was either, since the individual that he identified was not "Maria," the research assistant whose name was written on the recorder, but rather another female researcher present at the school. Furthermore, their subsequent conversation confirmed that the discursive position of a desirable and sexual object was not only ascribed to "Maria," but also to another of the young female researchers present at the school, whom they described as "chok porrig" [very porno-like].

\section{Discussion}

Researchers will occasionally encounter situations that fall outside the scope of their research, and that may be at odds with their knowledge interests. In such situations, they are at risk of lacking suitable tools for understanding the dynamics of these research practices, as well as the data they generate. This, we argue, is what characterized the SUF researchers' initial treatment of the data scrutinized in the present article. While they found this data interesting, it was omitted from publication because of its sexist content. The SUF project's strong empirical focus, favoring naturalistic, minimally reflexive data, was paired with an ambition to overcome prevalent stereotypes of urban non-standard Swedish that were in circulation at the time (Boyd 2010). The latter strategy, one could argue, was grounded in ethical and advocacy concerns (Cameron et al. 1993). As the purpose of the unmonitored recording was not to capture vulgarities, but simply "natural discourse," the choice to exempt it from publication could be understood as an ethically motivated attempt to create a "representative" account of the participants' ways of speaking. With the analytical tools they used at the time, the SUF researchers would have been forced to interpret the overt sexism unfolding in the data as a factual trait of the participants' authentic personae, rather than as acts of performance. For this reason, in retrospect, it is fully understandable why the data was withheld. Publishing it would have risked compromising the moral character of the participants, as well as 
reproducing the very sociolinguistic stereotypes that the SUF project sought to overcome (see Boyd 2010). Given the wealth of data, the researchers' decision to use other exemplifications of linguistic traits is understandable.

Nevertheless, in light of the arguments and analyses presented in this article, we maintain that the same data can contribute to a deepened understanding of some of the fundamental dynamics within sociolinguistic research on multilingualism (cf. Jaspers and Meeuwis 2013; Jonsson and Milani 2012). Any research on living subjects is bound to encompass some durable forms of domination. The privilege of knowledge production presupposes, on the one hand, a form of social dominance of the researcher over the researched. On the other hand, this social relation is closely tied to relations of symbolic dominance, that is, to engrained ideas and representations of the linguistic and the social. In our analyses of the residual material from the SUF project, it may appear as if symbolic violence begets symbolic violence, or as if research is merely a symbolically violent affair. This is not our suggestion. What we do suggest, however, is that sociolinguistic research on disempowered agents representationally and otherwise - calls for a certain mode of reflexivity. Whenever sociolinguistic research is undertaken with, and hence is interested in, such dominated agents, it is imperative, we maintain, that researchers strive to achieve an understanding of these patterns of domination, of the inherent risk of reiterating them, as well as of the possibility of exposing and circumventing them (Bourdieu 1996).

This lens allows us to grasp the sociolinguistics of the sociolinguistic research setting. Moreover, it allows us to distinguish between the principal elements of symbolic violence - domination and complicity - and to recognize their interactional unfolding in the research practice. As the reanalyzed SUF data indicates, even a short sequence of sociolinguistic data may be shot through with several symbolically violent manifestations. One distinct example is found in Excerpts 2-4, where the participants' appraisals of urban non-standard Swedish complied with engrained, pre-analytical stereotypes about people who speak this way. The participants discussed the stylized register of a literary work by means of ethnic slurs and caricatures - the "wannabe svartskalle," the "chat Turk," the "Iranian electrician" - as well as their antipode, the "purespeaking Swede." By symbolically linking non-standard forms of Swedish to notions of deficiency and otherness, to senses of subordination and marginality, they aligned with widely upheld representations of the presumed sociolinguistic character of non-standard Swedish in general and of RS in particular (cf. Jonsson and Milani 2012; Milani and Jonsson 2011). Perhaps contrary to the SUF researchers' expectations, the participants' own appraisal of the urban non-standard forms of Swedish was not, at least in this piece of data, laudatory. Another, 
perhaps more overt form of symbolic violence is closely connected to this mode of complicity. As Bourdieu (1991: 51) argues, "the legitimacy of the official language has nothing in common with an explicitly professed, deliberate and revocable belief, or with an intentional act of accepting a 'norm'." Complicity with the sociolinguistic order, in this regard, is not the same thing as passive resignation to this order. On the contrary, it may at times require seemingly agentive contributions from those placed at the lower end of the relation of domination.

Bourdieu (1996) envisions research as a relationship with multiple and complex effects and, importantly, it is "all the more so as those who are investigated can also play on those effects, consciously or otherwise, to attempt to impose their own definition of the situation and turn to their advantage an interchange" (p. 25). This too has been duly exemplified in this paper. As seen in Excerpts 6-8, the participants leveled sexually explicit comments at some of the involved female researchers. These verbal aggressions, we argue, should be regarded as instantiations of a deep-seated mode of masculine domination, that is, as another form of symbolic violence. Speaking to this claim is the fact that the researchers appear to have responded with silence to these acts of symbolic violence. When reporting on the study, rather than foregrounding the participants' assertions about the alleged promiscuity of the female researcher (Excerpts 6-8) - a move that would stress the need for an analytical grid able to grasp the modes of dominance invested in these assertions - they privileged other pieces of data. Bearing in mind that the researchers, as the participants had expected, listened to, talked about and even transcribed these utterances, their complicity was evident. Indeed, they found the utterances unsettling, but did not in any way hold the participants accountable for them.

\section{Conclusion}

The methodological design of the SUF project motivated leaving the participants alone with the recording device in order to capture some of their "natural discourse." Unintentionally, however, the data turned out to reveal less about the participants' authentic speech than it did about their conceptions of the research event, including their own position in it. In this article, we argue that instead of concealing their run-ins with symbolic violence, as was done in the SUF project, researchers can put them to use to make visible the patterns of dominance woven into and realized in the research practice. Analyzing these run-ins may push scholars to reflexively consider the social conditions of 
sociolinguistic research, in relation to the data it produces. We hold that Bourdieu's notion of symbolic violence is particularly apt for engaging, in depth and reflexively, with these dynamics because it brings to central stage a relational, dual mode of domination that "presupposes, on the part of those who submit to it, a form of complicity which is neither passive submission to external constraint nor a free adherence to values" (Bourdieu 1991: $50 \mathrm{f}$.). The primary advantage of consistently seeking to implement this point of view concerns epistemological rigor, since symbolic violence can only be broken by a radical transformation of the social conditions that have allowed it to arise (Bourdieu 2001: 41-42). This may in turn lead the dominated to take the point of view of the dominant - and vice versa. Such a reflexive exercise may help sociolinguists sharpen their tools for understanding the give and take of dominance and complicity that unfolds in their data, which, as we have shown, might constitute merely one thread in a larger weave of symbolic violence.

\section{Transcription key}

$\#=$ short pause

$\mathrm{X}+=$ self-interruption

$+/ .=$ speech interrupted by another speaker

$<[>]=$ simultaneous speech

[\%] = commentary

$<\ldots>$ [?] = uncertain transcription

$(\mathrm{xxx})=$ inaudible

Acknowledgements: The paper draws on empirical data from the project "Language and Language Use among Young People in Multilingual Urban Settings", funded by the Swedish Foundation for Humanities and Social Sciences 2001-2006. We wish to thank the following colleagues for valuable comments on an earlier draft of this paper: Ellen Bijvoet, Hannah Botsis, Linnea Hanell, Christina Hedman, and Maria Rydell. Thank you also to one of the anonymous reviewers for constructive critique.

\section{References}

Bauman, Richard. 2004. A world of others' words: Cross-cultural perspectives on intertextuality. Malden: Blackwell Publishing. 
Bijvoet, Ellen \& Kari Fraurud. 2012. Studying high-level (L1-L2) language development and use among young people in multilingual Stockholm: the role of perceptions of ambient sociolinguistic variation. Studies in Second Language Acquisition 34(2). 291-319.

Bourdieu, Pierre. 1991. Language \& symbolic power. Cambridge: Polity.

Bourdieu, Pierre. 1996. Understanding. Theory, Culture, Society 13(2). 17-37.

Bourdieu, Pierre. 2001. Masculine domination. Cambridge: Polity.

Bourdieu, Pierre. 2007. Sketch for a self-analysis. Cambridge: Polity.

Bourdieu, Pierre \& Jean-Claude Passeron. 1977. Reproduction in education, society and culture. London: Sage Publications.

Bourdieu, Pierre \& Loïc Wacquant. 1992. An invitation to reflexive sociology. Cambridge: Polity. Boyd, Sally. 2010. Research on language in multilingual urban settings in Sweden. In Pia Quist \& Bente Ailin Svendsen (eds.), Multilingual urban scandinavia: New linguistic practices, 1-5. Clevedon: Multilingual Matters.

Briggs, Charles. 2003. Interviewing, power/ knowledge,and social inequality. In Jaber Gubrium \& James A. Holstein (eds.), Postmodern interviewing, 242-254. London: Sage Publications.

Cameron, Deborah, Elisabeth Frazer, Penelope Harvey, Ben Rampton \& Kay Richardson. 1993. Ethics, advocacy and empowerment: Issues of method in researching language. Language \& Communication 13(2). 81-94.

Cameron, Deborah \& Don Kulick. 2003. Language and sexuality. Cambridge: Cambridge University Press.

Ganuza, Natalia. 2008. Syntactic variation in the Swedish of adolescents in multilingual urban settings: Subject-verb order in declaratives, questions and subordinate clauses. PhD diss. Stockholm: Stockholm University.

Goffman, Erving. 1974. Frame analysis. New York: Harper and Row.

Grenfell, Michael. 2012. Pierre Bourdieu: Key concepts. Durham: Acumen Publishing.

Heller, Monica. 2011. Paths to post-nationalism. A critical ethnography of language and identity. Oxford: Oxford University Press.

Heller, Monica \& Mireille. McLaughlin. 2017. Language choice and symbolic domination. In Stanton Wortham, Deoksoon Kim \& Stephen May (eds.), Discourse and education: Encyclopedia of language and education, 87-95. Cham, Switzerland: Springer International Publishing.

Jaspers, Jürgen \& Michael. Meeuwis. 2013. Away with linguists! Normativity, inequality and metascientific reflexivity in sociolinguistic fieldwork. Multilingua 32(6). 725-749.

Jonsson, Rickard. 2007. Blatte betyder kompis: Om maskulinitet och språk i en högstadieskola. Stockholm: Ordfront förlag.

Jonsson, Rickard \& Tommaso M. Milani. 2012. Du baza henne fem - om sexistiskt språk och den Andre. In Lucas Gottzén \& Rickard Jonsson (eds.), Andra män: Maskulinitet, jämställdhet och normskapande, 93-114. Malmö: Gleerups.

Källström, Roger. 2005. Litterärt språk på tvärs. Lite om språket hos Leiva Wenger och Hassen Khemiri. In Boel De Geer \& Anna Malmbjer (eds.), Språk på tvärs: Rapport från ASLA: shöstsymposium, Södertörn. 11-12 november 2004, 147-158. Uppsala: ASLA.

Kiesling, Scott. 2005. Homosocial desire in men's talk. Balancing and recreating cultural discourses of masculinity. Language in Society 34(5). 695-726.

Kotsinas, Ulla-Britt. 1988. Immigrant children's Swedish: A new variety? Journal of Multilingual and Multicultural Development 9(1-2). 129-140.

Kotsinas, Ulla-Britt. 1994. Ungdomsspråk. Uppsala: Hallgren \& Fallgren. 
Labov, William. 1972. Language in the inner city. Studies in the black English vernacular. Philadephia: University of Pennsylvania Press.

Leiva Wenger, Alejandro. 2001. Till vår ära. Stockholm: Albert Bonniers Förlag.

Madsen, Lian Malai. 2015. Fighters, girls and other identities. Sociolinguistics in a martial arts club. Clevedon: Multilingual Matters.

Milani, Tommaso M. 2010. What's in a name? Language ideology and social differentiation in a Swedish print-mediated debate. Journal of Sociolinguistics 14(1). 116-142.

Milani, Tommaso M. \& Rickard. Jonsson. 2011. Incomprehensible language? Language, ethnicity and heterosexual masculinity in a Swedish school. Gender and Language 5(2). 241-269.

Milani, Tommaso M. \& Rickard Jonsson. 2012. Who's afraid of rinkeby Swedish? Stylization, complicity, resistance. Journal of Linguistic Anthropology 22(1). 44-63.

Nortier, Jacomine \& Bente Ailin Svendsen. 2015. Language, youth and identity in the twenty-first century: Linguistic practices across urban spaces. Cambridge: Cambridge University Press.

Quist, Pia \& Bente Ailin. Svendsen. 2010. Multilingual urban scandinavia: New linguistic practices. Clevedon: Multilingual Matters.

Rampton, Ben. 2006. Language in late modernity. Interaction in an urban school. Cambridge: Cambridge University Press.

Salö, Linus. 2018. Seeing the point from which you see what you see: An essay on epistemic reflexivity in language research. Multilingual Margins 5(1). 24-39.

Slembrouck, Stef. 2004. Reflexivity and the research interview. Habitus and social class in parents' accounts of children in public care. Critical Discourse Studies 1(1). 91-112.

Smalley, Nichola. 2012. Lost in thought: Authenticity in rap and literature - a Swedish case study. Opticon1826 13. 33-44.

Stroud, Christopher. 2004. Rinkeby Swedish and semilingualism in language ideological debates: A bourdieuan perspective. Journal of Sociolinguistics 8(2). 196-214.

Werndin, Marie. 2010. Identitetsförhandlingar i det flerspråkiga klassrummet: om ungdomsspråk, makt och diskurs. In Nigel Musk \& Åsa Wedin (eds.), Flerspråkighet, identitet och lärande: skola i ett föränderligt samhälle, 97-126. Lund: Studentlitteratur. 